\title{
The Foreign Learners' Difficulties in English Speaking and How to Solve the Problems
}

\author{
Sabariyanto \\ Tarbiyah Faculty of science, IAIN Surakarta, Central Java, Indonesia \\ Email: sabariyanto@iain-surakarta.ac.id* \\ ${ }^{*}$ Coresponding Author
}

Article history: received October 27, 2020; accepted March 20, 2021; published April 25, 2021

\begin{abstract}
The objectives of this research are (1) to describe the difficulties faced by a foreign learner in English Speaking; and (2) to describe the foreign learner's solutions to solve the difficulties faced in English speaking. The design of this research is descriptive qualitative research. The result of this research showed that foreign learners did face difficulties in performing English conversation. The difficulties were categorized into four points, following Penny Ur's theory: inhibition, nothing to say, low or uneven participation, and mother-tongue use. There are four points for resolving the difficulties, following Jeremy Harmer's theory: preparation, repetition, big groups, small groups, or mandatory participation. Moreover, the foreign learners used the improvising strategy by Jeremy Harmer to help themselves develop the speaking ability; foreign learners used the repetition strategy by Jeremy Harmer.
\end{abstract}

Keywords: Foreign Learners' Difficulties; English Speaking; English Conversation

Copyright $\odot 2021$ The Author(s)

This is an open-access article under the CC BY-SA license.

\section{INTRODUCTION}

In learning English, four main skills need to be mastered by the students. There are four language skills: listening, reading, speaking, and writing (Gillett et al., 2014; Mart, 2012; Sadiku, 2015). These four cannot be separated as they are connected to one another in helping to comprehend English overall, so students should fully understand every skill. Among those skills, one of the most important to learn is speaking.

Speaking is essential in learning English since it is the main form of communication to deliver messages to other people (Bahadorfar \& Omidvar, 2014). Babita (2013); and Marriam Bashir; Muhammad Azeem; Ashiq Hussain Dogar (2016) speaking is the most important skill out of four (listening, speaking, reading, and writing) because people who know a language are referred to as 'speaker' of that language, and many language learners are primarily interested in learning to speak. In conclusion, it is understood that through speaking, someone can communicate or express their ideas in order to understand one another. According to Leong \& Ahmadi (2017) and Abrar et al. (2018) speaking is an interactive process of constructing meaning that involves producing, receiving, and processing information.

Gan (2012) and M. Al-Tamimi \& Attamimi (2014) defines speaking as an oral skill that is used to express a person's understanding, convey intended meaning accurately with sufficient vocabulary, use language in appropriate contexts, and interact with other speakers fluently. Some of the meanings may be able to be understood automatically, while others may need to be processed first.

Based on some definitions above, it can be concluded that speaking is a process to convey and share ideas or information orally. However, speaking in a foreign language needs many 
Sabariyanto | The Foreign Learners' Difficulties in English Speaking and How to Solve the Problems

practices. The learners know about the written theory of languages such as grammar, pronunciation, or vocabulary and have to know how to use it in oral communication. In order to carry out successful speaking, they have to fulfill some characteristics of successful speaking activity (Samira Al Hosni 2014):

Learner talks a lot

Students talk a lot in the class when they express their ideas. However, often most time is taken up by the teacher to talk or give feedback.

Participation is even

Learners get the same chance to contribute to express their ideas. A minority of talk-active participants does not dominate classroom discussion.

High motivation

Learners are willing to speak because they are interested in the topic and have something new to say about the topic. They want to contribute to achieving a task objective.

Language is of an acceptable level

Learners express themselves in utterances that are relevant, easily comprehensible to teach others, and acceptable language accuracy.

Derakhshan et al. (2016), Gilakjani et al. (2011), and Pourhosein Gilakjani (2011) say that speak fluently in English is about having the ability to pronounce phonemes correctly, use appropriate stress and intonation patterns, and speak in connected speech, but there is more to it than that. Speakers of English-especially where it is a second language, will have to be able to speak in a range of different genres and situations, and they will have to be able to use a range of conversational and conversational repair strategies. They will need to be able to survive in typical functional exchanges, too.

Learning English speaking as a foreign language is a complex process for students. They have to understand how and when to use it correctly, and it is not exactly an easy task for nonnative English speakers like Indonesian students. In the process of learning, students may encounter some problems that came from anywhere. Those problems can hinder students' process in learning; hence it creates difficulties, in this case, to their speaking ability. Then, Nunan (1991:6) demonstrates in his book that researchers undertaking conversational and interactional analysis have also shown that interactions do not unfold neatly like textbook dialogues and that meanings do not come ready-made. Further, Nunan also states that concerning speaking and oral interaction, learners need the ability to articulate phonological features of the language comprehensibly; mastery of stress, rhythm, intonation patterns; an acceptable degree of fluency; transactional and interpersonal skills; skills in taking short and long speaking turns; skills in the management of interaction; skills in negotiating to mean; and the others.

The students will face problems and make mistakes when writing or speaking more freely. Gilakjani et al. (2011) states that students will not always use correct English. Some students will make slips or errors when they try to utter words, phrases, or sentences in learning English speaking. From that statement, the researcher is interested in studying difficulties faced by students in their speaking ability, and the chosen place to conduct the research is at SMPN 1 Colomadu, Karanganyar. Central Java. The researcher is interested in conducting the study in that school because he wanted to see what phenomenon exists among students when learning English, noting that they are not native speakers.

The study aims to describe the difficulties students face in English speaking and describe the students' solutions to solve the difficulties faced in English speaking. Some problems make speaking difficult in talking English in the classroom (Gudu, 2015; Nazara, 2011; Quinn, 2014). Those problems are described as follow: 
Sabariyanto | The Foreign Learners' Difficulties in English Speaking and How to Solve the Problems

\section{Inhibition}

Unlike reading, writing, and listening activities, speaking requires some degree of real-time exposure to an audience. Learners are often inhibited about trying to say things in a foreign language in the classroom: worried about making mistakes, fearful of criticism or losing face, or simply shy of the attention that their speech attracts.

Nothing to say

Even if they are not inhibited, learners often complain that they cannot think of anything: they have no motive to express themselves beyond the guilty feeling they should be speaking. Low or uneven participation

Only one participant can talk at a time if he or she is to be heard, and in a large group, each one will have only very little talking time. This problem is compounded by the tendency of some learners to dominate, while others speak very little or not at all.

\section{Mother-tongue use}

In classes where all or a number of the learners share the same mother tongue, they may tend to use it; because it is easier, because it feels unnatural to speak to one another in a foreign language, and because they feel less 'exposed' if they are speaking their mother tongue. If they are talking in small groups, it can be pretty tricky to get some classes - particularly the less disciplined or motivated ones - to keep to the target language.

In solving difficulties students face when they speak English, Harmer (2007:140) talks about students' effectiveness at monitoring and judging their own language production. Through students' self-assessment, they have an obvious idea of how well they are doing or have done, and if the teacher helps them devise this awareness, all of them may significantly enhance learning. Before they solve the problems, it is best that they first understood well of their speaking ability with this self-assessment.

This kind of self-evaluation is at the heart of the 'can do' statements from ALTE (Association of Language Testers in Europe) and the Common European Framework (CEF). Students - in many different languages - can measure themselves by saying what they can do in various skill areas; with six levels from $A_{1}-C_{2}$, the table will give students clear statements of ability against which to measure themselves.

After measuring and understanding how far students have become in their speaking ability, they may employ some or all of the following strategies to resolve the difficulty: (Harmer, 2007:277)

\section{Improvising}

In this strategy, when students face problems speaking a word, they sometimes try any word or phrase they can come up with, hoping that it is correct. Such improvisations sometimes work, but they can also obscure meaning.

Discarding

When speakers cannot find words for what they want to say, they may abandon the thought they cannot put into words.

Foreignising

When operating in a foreign language, students sometimes choose a word in a language they know well (such as their first language) and 'foreignize' it (in other words, pronounce it as if it was an L2 word)in the hope that it will be equivalent to the meaning they wish to express in the foreign language.

Paraphrasing

Students sometimes paraphrase, talking about something for cleaning the teeth if they do not know the word toothbrush, or saying that they have very bad feelings about somebody when all they want to say is that they are cross with that person. 
Sabariyanto | The Foreign Learners' Difficulties in English Speaking and How to Solve the Problems

Clearly, some of those difficulty strategies are more appropriate than others, so the teacher should encourage paraphrasing and improvising as more useful techniques than discarding thoughts or foreignizing words blindly.

Harmer (2007) describes that students are often reluctant to speak because they are shy and not predisposed to expressing themselves in front of other people, especially when they are being asked to give personal information or opinions. There is also a worry about speaking badly and therefore losing face in front of their classmates. In such situations, there are many things that students can do to help themselves.

Preparation

Mennim (2003) in Harmer (2007:346) describes how students record presentations they are going to make and transcribe what they have said, correct it, then hand it over to the teacher for further comment before finally making the presentation.

At other times, where students will take part in a discussion, they can put themselves in buzz groups to brainstorm ideas, so they have something to say when the honest discussion happens.

Repetition

Repetition has many beneficial effects-each new encounter with a word or phrase helps to fix it in the students' memory. Repetition also allows them to improve on what they did before. They can think about how to re-word things or just get a feel for how it sounds.

When students repeat speaking tasks they have already done once (or twice), their first attempt is like a rehearsal for the final effort. Each rehearsal gives them more confidence as they are not attempting to get the words out for the first time when they try to speak in subsequent 'performances'.

Big groups, small groups

A significant reason for the reluctance of some students to take part in speaking activities is that they find themselves having to talk in front of a big group. A way of counteracting this is by making sure that they get chances to speak and interact in smaller groups. This can be prepared for dialogue-making or discussion.

Mandatory participation

Littlewood (2004b) in Harmer (2007:347) states that when groups do a task, there will always be 'social loafers', the students who sit back and let everyone else do the work. To ensure that all students were equally engaged in a task, he called one of his ideas 'numbered heads': in each group of four, for example, the students are asked to assign a number from 1 to 4 to each member, without telling the teacher who has which number.

At the end of an activity, the teacher indicates a group and a number (1-4) and asks that student to report on what happened. Neither the teacher nor the students know who will be called, and, as a result, all the students have to stay on-task.

\section{METHOD}

The subjects of this study are eighth-grade students in the second semester of SMPN 1 Colomadu, Karanganyar, Central Java, in the academic year 2019/2020. From 8A-8G classes, there are 217 students, consists of 133 male students and 84 female students. The researcher took 24 students from four classes (8A, 8C, 8D, and $8 \mathrm{E}$ ).

The technique of collecting the data was by questionnaire. (Arikunto, 2010) describes a questionnaire as a list of the question given to others who are willing to respond following user requests. In this study, the researcher used a semi-open questionnaire to collect the data. According to Glerum et al. (2013:3), in the semi-open questionnaire, the subjects must reply to a more precise question by giving them more structured answers. 
Sabariyanto | The Foreign Learners' Difficulties in English Speaking and How to Solve the Problems

The benefits of using this type of questionnaire are many. If the answers can get too heterogeneous and complex to sort out in an open questionnaire, the answers are too narrow in a closed questionnaire. Then in a semi-open questionnaire, the response scale is wide enough yet structured as well. The researcher used this kind of questionnaire because of the effectiveness that this type can provide. The questionnaire with a combination like this means the researcher has prepared answer choices, but the researcher also gives freedom to the respondents if they had their answer.

The second technique collecting data was an in-depth interview. The main point of this study was to know how far the students' ability in speaking English, especially in every English class they did. In-depth interview in this study was because Ary et al. (2010:438) state that interview is one of the most widely used and basic methods for obtaining qualitative data. Interviews are used to gather data from people about opinions, beliefs, and feeling about situations in their own words.

In this study, the researcher used personal interviews. This method requires a person known as the interviewer to ask questions generally in contact with other person/s. In this case, the researcher acted as the interviewer and the students as the interviewee. Since this interview had a role as the supporting evidence of the questionnaire result, so the researcher asked 10 out of 24 subjects to strengthen the data. The questions were also based on Penny Ur's four points of the speaking problem and the strategy to resolve the difficulties by Jeremy Harmer, but each question is not transfixed to the same items.

\section{RESULT AND DISCUSSION}

\section{Students' Difficulties in Performing English Conversation}

These problems were specified on Penny Ur's theory (1991:121) about students speaking problem in class, consist of four categories: inhibition, nothing to say, low or uneven participation, and mother tongue use.

Data for this one research objective were collected from the questionnaire that has been spread out to the 24 research subjects via Google Forms, and interview with ten out of 24 participants-a pair of students from each class $(8 \mathrm{~A}, 8 \mathrm{C}, 8 \mathrm{D}$, and $8 \mathrm{E})$-via Voice Note on WhatsApp.

Inhibition

Toward the question: Do you often faced inhibition when performing English speaking in class? From 24 respondents, there were three answers; 12 students with an answer "sometimes", 8 students with an answer "rarely", and the other 4 with with an answer "often". The answer that got the most number was "sometimes", so the researcher took that one. Then, the answer was supported with statements from students in the interview.

PTJ: Every time I have a conversation in English, I often get nervous. I am afraid if I pronounce it wrong.

BMK: The obstacles that I encountered when having conversations in English in class were pronunciation, sometimes forgetting, and being nervous about having a conversation for fear of pronouncing it wrong.

SS: My obstacle in speaking English is fear of wrong speech and misunderstanding.

The second question was 'What kind of inhibition do you faced when performing English speaking in class?'. From 24 respondents, there are five answers. 15 students answered they "worried about mistakes in saying words/sentences", 6 students "nervous when speaking in public", and 3 students answered they "do not know the meaning". With that result, the researcher reduced it more into only two that got the most number; they worried about mistakes in saying words/sentences and nervous when speaking in public. The most answer they are worried about mistakes in saying words/sentences. 
Sabariyanto | The Foreign Learners' Difficulties in English Speaking and How to Solve the Problems

Based on the questionnaire and interview result, students admitted that they sometimes faced inhibition in making English conversation in class. They were mainly worried about making mistakes when speaking in front of the class, and then they felt nervous about doing that in public. Students were also rarely had the initiative to speak English independently, but when they did, they sometimes only did it with one or two friends, not in front of many friends.

\section{Nothing to Say}

Toward a question: are you fluent in English? From 24 respondents, there were three answers; 18 students answered "not so fluent", 4 students answered "fluent", and the other answered "not fluent". The most answered "not so fluent", so the researcher took that one. Statements from students in the interview supported this answer.

BMK: ... if I forget the word/sentence, it makes me stifle because it is really difficult to speak English.

YGD: I'm just afraid that the pronunciation is wrong, sir.

The other question was 'Do you often have the initiative to start a conversation in English?'. From 24 respondents, there are 4 answers with two pairs of even numbers; 9 students answered "sometimes", 9 students answered "rarely", 3 students answered "often", and the others answered "never". With that result, the researcher reduced it into two most answers; "sometimes" and "often". The answer that got the most number was "sometimes", so the researcher took that one. Statements from students in the interview supported this answer.

YS: Rarely, sir. If the teacher does not tell me, I do not speak.

NMI: Yes, sir. Sometimes I speak English, but at most just answer yes or no.

WAR: Yes, sometimes I have, sir. I talk to friends, but the language is all that's it.

Based on the questionnaire and interview results, most students were not so fluent in speaking English. These problems made them feel difficult to talk. Therefore they were indifferent to the idea of speaking English in class. Although some students admitted that they felt proud of themselves when they could perform English conversation correctly, most of their initiative to start a conversation was on 'sometimes', so most of the time, they were not active in the English speaking activity.

Low or uneven participation

Toward a question: Does your teacher often asked you to practice English conversation in class? From 24 respondents, there were four answers; 8 students answered "rarely", 7 students answered "often", the other 7 with answered "sometimes", and 2 other students answered "very often". With that result, the researcher reduced it more into only two answers that rarely and often got the most. The most answer was rarely, so the researcher took that one. Statements from students in the interview supported this answer.

AS: I am one of many people who rarely talk.

AIN: I am passive, sir. Because I am not very active in English either, actually, if there is a chance, I really want to come to the front of the class, but I'm afraid if the words are wrong.

The other question was 'Are you the student who often conversed using English in class?'. From 24 respondents, there were four answers; 12 students answered "rarely", 8 students answered "sometimes", 3 students answered "never", and one student answered "often". With that result, the researcher reduced it more into only two answers that rarely and sometimes got the most number. The most answer is rarely, so the researcher took that one.

Based on the questionnaire and interview results, a significant number showed that students were rarely engaged in English speaking activity, let alone English conversation. Even though a small number of students often participated in English speaking activity in class, most of them felt free to speak English when they chatted with their friends or when the teacher was not around. Most students also rarely got asked by the teacher to practice English conversation in class, so they were passive to perform English conversation. 
Sabariyanto | The Foreign Learners' Difficulties in English Speaking and How to Solve the Problems

\section{Mother Tongue Use}

Toward question: 'When somebody conversed to you in English, did you respond in English as well?' From 24 respondents, there were three answers; 15 students answered "sometimes", 4 students answered "rarely", 2 students answered "never", the other answered "often", and one student answerd "always". With that result, the researcher reduced it more into only three that got the most number are sometimes, rarely, and never. The most answer is sometimes, so the researcher took that one.

This answer was supported by students' statements from one question in the interview 'Can you understand when people talk to you in English?'

PTJ: I know, but I am usually a little hesitant.

WAR: Not really, sir.

The other question was 'How is your ability in understanding English in general?'. From 24 respondents, there were three answers; 15 students answered "quite understand", 8 students answered "understand", and one student answered "very understand". With that result, the researcher reduced it more into only two answers that got the most number; quite understand and understand. The most answer was quite understand.

Another question was 'Since when do you learn to speak English?'. From 24 respondents, there were three main answers that got the most numbers; Sekolah Dasar (Elementary School), Taman Kanak-Kanak (Kindergarten), and Sekolah Menengah Pertama (Junior High School). The most answer was Elementary School, so the researcher took that one. From this data, the researcher drew a conclusion that students learned English speaking since they were in Elementary School.

Based on the questionnaire and interview result, students did not understand the English language well, added with their lack of ability in mastering English speaking. They only started learning English at Elementary Schools, and they did not always respond in English when somebody spoke English to them-only sometimes, tend to rarely, and even never. This means students still use their mother tongue when someone talked to them using English.

\section{Students' Solutions to Solve The Difficulties Faced in Performing English Conversation}

The researcher obtained the data of this finding from the questionnaire that has been conducted, supported with the interview. For the question 'When you faced difficulties in speaking English, what did you do to resolve them?', most students answered that they tried to improve words they do not understand. This means they used an improvising strategy from Harmer to solve the difficulties in performing English conversation. In improvising, every time students face difficulties speaking, they tried any word or phrase that they can come up with in the hope that it is about right.

Next, for the question 'To train your ability in speaking English, what do you do?', most students answered that they repeated word/sentence in English to get used to and can say it correctly. This means students used repetition strategy to help themselves develop speaking ability in order to be able to perform English conversation well. Poeja, one of the research subjects, also admitted that she recites vocabularies to develop her speaking ability. Recitation can be included as the part of repetition, as the activity of reciting means getting used to the feel and 'taste' of the words in the tongue, so over time, the words would be easy to speak up. Besides, some students also stated that they watched movies/videos in English to accustom them to speak. By watching and listening to the way people in videos talk, students would understand the correct way to pronounce words, the intonation, and when they can use particular expressions to make a conversation. 
Sabariyanto | The Foreign Learners' Difficulties in English Speaking and How to Solve the Problems

\section{CONCLUSION}

This section draws the conclusion of this study. The difficulties faced by eighth-grade students of SMPN 1 Colomadu, Karanganyar, Central Java, in performing English speaking, each student encounters various kinds of difficulty, as stated by Penny Ur's theory that describes the four points of students' speaking problem in class, they are: Inhibition, Nothing to say, Low or uneven participation, and Mother-tongue use. Most students worry about making mistakes for inhibition point when they have to speak English in public, so they feel nervous about performing their conversation. In nothing to say, most students are not fluent enough to speak English well, making them feel difficult to perform their conversation. Most students tend to be passive for the low or uneven participation point when it comes to English speaking class, so they do not have many opportunities to perform English conversation. In mother-tongue use, most students could not always speak back in English when somebody conversed with them-in; in other words, they primarily respond in Indonesian, so they cannot perform conversation using English correctly.

Students use some strategies to overcome the difficulties in performing English speaking. These strategies are based on Jeremy Harmer's theory of students' strategies to resolve the difficulty in speaking performance. They are improvising, discarding, foreignizing, or paraphrasing. From the study results, most students try to improve words that they do not understand to speak. So, among four categories of Harmer's theory, students in SMPN 1 Colomadu, Karanganyar, Central Java, use the improvising strategy to solve the difficulties in performing English conversation. For the things that students can do to help themselves develop their speaking skills, it is also based on Harmer's four categories: preparation, repetition, big groups, small groups, or mandatory participation. The result showed that students do repeat words/sentences in English to get used to the feeling on their tongue. This means students use the repetition strategy to improve their speaking ability in order to be able to say the word/sentence correctly.

\section{REFERENCES}

Abrar, M., Mukminin, A., Habibi, A., Asyrafi, F., Makmur, M., \& Marzulina, L. (2018). “If our English isn't a language, what is it?" Indonesian EFL Student Teachers' Challenges Speaking English. The Qualitative Report, 23(1), 129-145. https://doi.org/10.46743/2160-3715/2018.3013

Arikunto, S. (2010). Prosedur Penelitian Pendidikan Suatu Pendekatan Praktik. Jakarta: Rineka Cipta.

Babita, T. (2013). Listening : An Important Skill and Its Various Aspects. The Criterion : An International Journal in English, 12, 1-8. www.the-criterion.com

Bahadorfar, M., \& Omidvar, R. (2014). (2014) Technology in teaching speaking skills.pdf. Acme International Journal of Multidisciplinary Research, II(IV), 9-13.

Bashir, Marriam; Azeem, Muhammad; Dogar, A. H. (2016). Factor Effecting Students' English Speaking Skills. British Journal of Arts and Social Sciences, 2(January 2011), 35-50.

Derakhshan, A., Khalili, A. N., \& Beheshti, F. (2016). Developing EFL Learner's Speaking Ability, Accuracy and Fluency. English Language and Literature Studies, 6(2), 177. https://doi.org/10.5539/ells.v6n2p177

Gan, Z. (2012). Understanding L2 speaking problems: Implications for ESL curriculum development in a teacher training institution in Hong Kong. Australian Journal of Teacher Education, 37(1), 43-59. https://doi.org/10.14221/ajte.2012v37n1.4

Gilakjani, A., Ahmadi, S., \& Ahmadi, M. (2011). Why is Pronunciation So Difficult to Learn? English Language Teaching, 4(3), 74-83. https://doi.org/10.5539/elt.v4n3p74

Gillett, A., Mansfield, K., Francis, J., Ngoran, K. M., Nhire, T., António, N., Muguiro, N. F., Díaz-santos, G., Mcdonnell, J., \& Carolan, D. (2014). Professional and Academic English. 43, 1-44.

Gudu, B. O. (2015). Teaching Speaking Skills in English Language Using Classroom Activities in Secondary School Level in Eldoret Municipality, Kenya. Journal of Education and Practice, 6(35), 55-63.

Harmer, J. (2007). The practice of English. In Language (FOURTH).

Leong, L., \& Ahmadi, S. M. (2017). An Analysis of Factors Influencing Learners' English Speaking Skill. 
Sabariyanto | The Foreign Learners' Difficulties in English Speaking and How to Solve the Problems

International Journal of Research in English Education, 8(2), 34-42.

M. Al-Tamimi, N. O., \& Attamimi, R. A. (2014). Effectiveness of Cooperative Learning in Enhancing Speaking Skills and Attitudes towards Learning English. International Journal of Linguistics, 6(4), 27. https://doi.org/10.5296/ijl.v6i4.6114

Mart, C. T. (2012). Developing Speaking Skills through Reading. International Journal of English Linguistics, 2(6). https://doi.org/10.5539/ijel.v2n6p91

Nazara, S. (2011). Students' Perception on EFL Speaking Skill Development. JET (Journal of English Teaching), 1(1), 28. https://doi.org/10.33541/jet.v1i1.50

Pourhosein Gilakjani, A. (2011). A Study on the Situation of Pronunciation Instruction in ESL/EFL Classrooms. Journal of Studies in Education, 1(1). https://doi.org/10.5296/jse.v1i1.924

Quinn, S. (2014). Problems and Difficulties of Speaking That Encounter English Language Students at Al Quds Open University. International Journal of Humanities and Social Science Invention, 5(12), 96101.

Sadiku, L. M. (2015). The Importance of Four Skills Reading, Speaking, Writing, Listening in a Lesson Hour. European Journal of Language and Literature, 1(1), 29. https://doi.org/10.26417/ejls.v1i1.p29-31

Samira Al Hosni. (2014). Speaking Difficulties Encountered by Young EFL Learners. English Language Teaching, 2(6), 22-30. 